報 $\quad$ 文

\title{
蓄電池隔離板電氣抵抗測定容器の改辰 ${ }^{*}$
}

\author{
大下利三郎中川辰次高橋修輔 \\ (彪信省電楀試驗所第五部)
}

\begin{abstract}
.
The customary cell for meastring the resistances of separators does not give the actual separator resistance. This paper describes the results and characteristics of a new cell which gives the correct resistance.
\end{abstract}

梗概

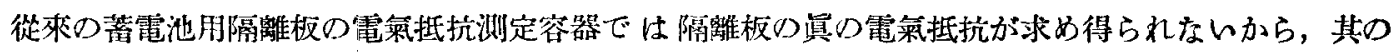
值を直接求め得る如き新しい测定容器を考案試作し, 其の特性湴儿测定值を記载した。

\section{I. 緒 言}

從來䈉電池湖隔離板の電氣抵抗として求められて來え 值は，實は德の隔離板の電氣抵抏ではなく，之より遥か て少ない電篓趔抗が表はされてるるゆである。從つて今 迄に發表された隔踓板の電氣抵抗の数值をその䍀, 隔離

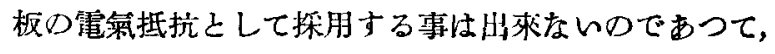
之に若下の補正を行はね代ならない。との事關しては 電氣工學ポケットブック に年簡單に記述されてるる。 この㛊謬の搵つて來を處は隔雜板の電氣抵抗測定容器に あるから，ての容器を改良するととが最も必要である。

本文性，從來の隔離板電氣抵执の實测值が有する意義 と, 從來の测定容器の缺點を除いた新容器とを述へ, 該 容器によつて测定した隔離板の電氣抵抗の䐝驗值を揭げ たものである。

\section{II. 從來の需離板電㴋抵抗測定容器と 惯测值の意義}

從來の隔離板電氣抵抗測定容器は, 第 1 圖に示せる如 く電極 $P$ 者取付けた電槽と，相對する兩面に悹 $A$ を有 する隔離板收容器 $C$ とから成立つてるる。實際の測定

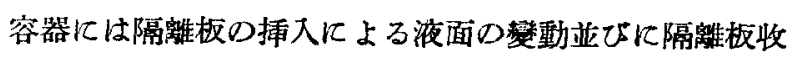
容器と慒壁との接面部の電氣漏洩を防ぐエ夫が疑らして
あるるのもるる。

隔離板》電氣抵抗は隔 離板收容器に隔踓板を掎 入した時（第 1 圖）の電 極間の液抵抗之，隔離板 を插入しない時のそれと の差で表はしてるる。從 つてての容器で測定され そ隔離板の電爭抵抗忙次

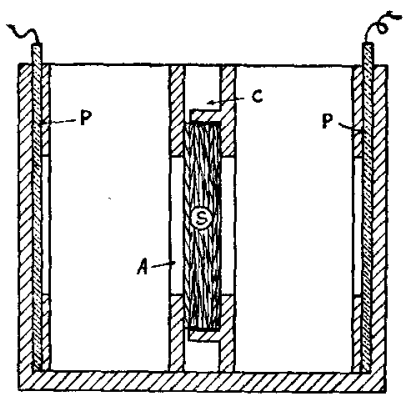

第 1 圖 從來の隔㗱板電氣 抵抗測定谷器 式で表はされる。

$$
\begin{aligned}
R_{s} & =R_{2}-R_{1} \\
& =R_{s 0}-R_{l}
\end{aligned}
$$

$R_{s}$ この容器によつて测定された隔蜼板の抵抗

$R_{2} \quad$ 隔離板を挿入した時の電極間の液抵抗

$R_{\mathrm{i}}$ 隔離板を挿入しない時の電樰間の液抵抗

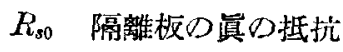

$R_{l} \quad$ 隔離板々同一厚さ, 同一の電流通過面皘の 液》抵抗

即ちこの答器に上つて測定された隔蜼板の電氣抵抗 は，眞の隔離板の電氣抵抗之，隔離板之同一厚さ同一電 流通過面積を有する液の抵抗との差であつて, 真の抵抗

\footnotetext{
* On the Reformation of the Cell for Measuring Resistance of Separators. by R. OSHITA, T. NAKAGAWA and

S. TAKAHASHI (Electrotechnical Laboratory, Ministry of Communications.)

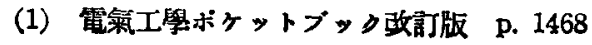


ではない。從つて真の抵抗を測定する䉆には， $R_{l}$ の影 響が加はらない樣な測定容器を使用しなければならぬ。 隔離板の萁の抵抗と虚抵抗（從來の測定容器で測つた 隔離板の抵抗）之の比は，隔離板の多孔度飞よつて異り 輕處理木製隔離板之强處理木製隔離板とではその值が相 當造つて來る。

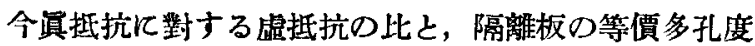
との關保を示すと第 2 圖の如くである。

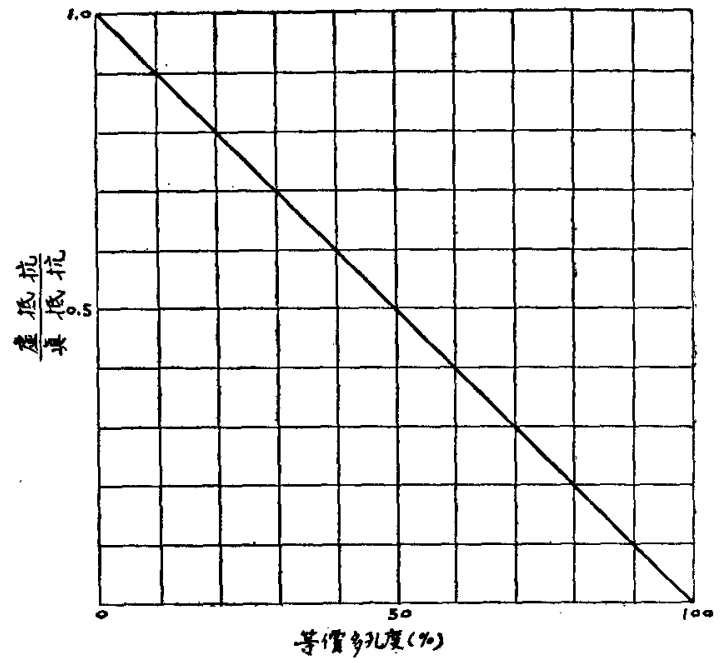

第 2 圖 拱抗比と多孔度との關係

市場で販賣されてわる木製隔離板の等價多孔度を三社 几就て調查した處大體，榀が $50 \%$ ，スプルスが $40 \%$ ， 米檜が $35 \%$ であつをから一般的な榀材几例をとつて見

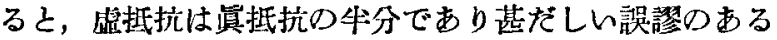
ととが制る。

虚抵抗即ち從來心测 定 值を活すためには補正を要す る。市販の木製隔離板に就て補正值を計算した感，大體 楅が 2, スプルスが 1.7，米檜が 1.5 であつたから，䍀 抵抗に之を乘亦れば大體の其の抵抗が得られる。

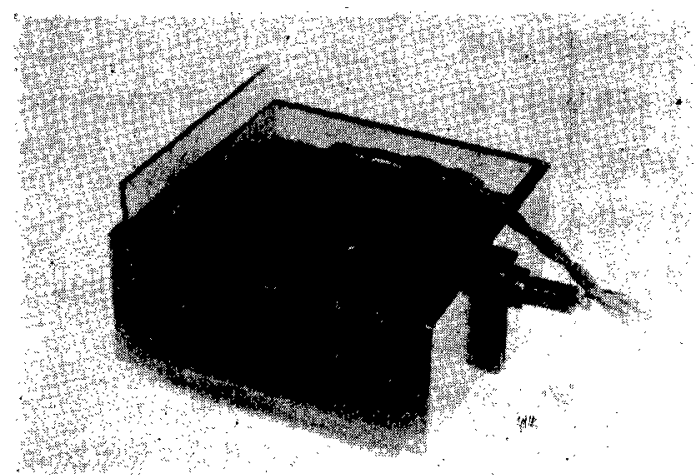

第 3 圆 新 测 定 容器

\section{III、當所で考案した隔離板電氣抵抗測定容器}

當所で考案した新測定容器は，隔離板の真心抵抗を直 接に求め得るやうにしたものであつて，第 3 圖は此の測

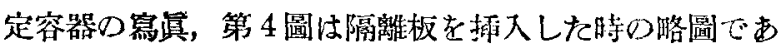
る。

本器の主要部はセルロイド製の蓋 $A$ と槽 $B$ とから成

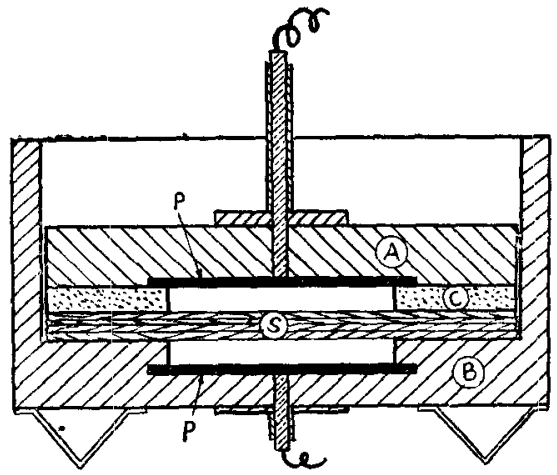

第 4 圆 新測定容器

立つてるる。槽の內法は縱横各 $110 \mathrm{~mm}$, 深さ $40 \mathrm{~mm}$ で あつて，ての底部中央には縱横各 $50 \mathrm{~mm}$, 深さ $3.5 \mathrm{~mm}$

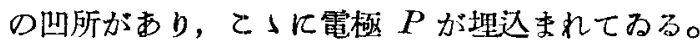

蓋の周邊には數個の圓孔が穿つてもり，蓋の下面中央 Кは電極 $P$ が取付けてある。猶蓋の队部には鐵板が假

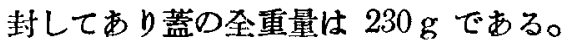

更に隔離板を容器几入れる第の隔離板受之，隔離板 と 蓝との閒に液間を設ける䉆のゴム板 $C$ が附虽してるる。 雨者共中央几，槽の凹所之同形同大の们孔が牚つてあ る。電極として鉛蓄電池の陰殹板，陽極板，炭素板，及 び白金黑白金板等に就いて檢べを處，白金黑白金板が最 を安定であつたから，本器にはてれを使倣した。陽極板 の安定性は之に亞ぐ。

隔離板の電氣抵抗の求め方は，從來のオ法之同樣であ つて隔離板を挿入した時の電極閒の液抵抵と隔離板を捚 入しない時のそれるの差を以てする。ての差はまさしく 隔離板の真の抵抗索示すのである。

新測定容器は水本式であるから蒕の重さが隔離板に掛 かる譯であるが，培及び槽の中央が凹んでるるから隔離

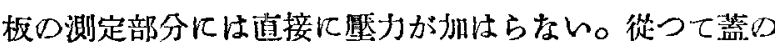
重さが變つても隔離板の抵抗は大した變化がないであら 与と考人得る。

蓝に荷重を加へで隔雖板の電氣抵抗を测定しそとて ろ，第 1 表の如き結果を得た。蓋の重さが㙁してる隔離 
板の電氣抵抗の增加は大したものでなく，荷重が 10 倍 になつて涑く抵抗が $1.5 \%$ 菂加する程度でする。

第 1 表 隔離炍の電氣抵抗に及ぼす荷重の影響

\begin{tabular}{|c|c|c|}
\hline 荷重 & (g) & 䨘测 提 抗 $(\Omega)$ \\
\hline \multirow[t]{8}{*}{ (搵涪重量) } & 230 & 0.0645 \\
\hline & 500 & $"$ \\
\hline & 750 & 0.0650 \\
\hline &, 000 & $"$ \\
\hline &, 500 & " \\
\hline &, 000 & 0.0655 \\
\hline & 2,250 & " \\
\hline &, 500 & $"$ \\
\hline
\end{tabular}

爻新测定容器には稚测定容器の如く漏洩がある。例し

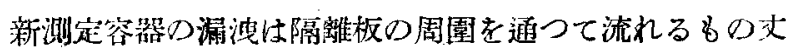
であつて然かもその值は小さら。

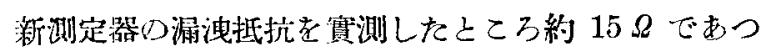
たから， $0.1 \Omega$ 比重 $1,200\left(15^{\circ} \mathrm{C}\right.$ に於る)の稀硫酸中に 於て $20^{\circ} \mathrm{C}$ に於ける $5 \mathrm{~mm}$ 厚の米檜の措抗に相當]の 抵抗を测定する場合でも，隔離板の䜌の抵抗の約 $0.6 \%$ 小さい值を示す文であつて大して問題にはならない。併

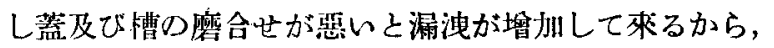

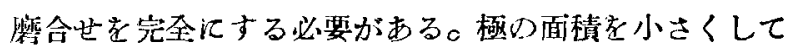
篮及び槽を大きくするととも漏洩》減少に役立つ。

\section{IV. 新, 㟟測定容器による實測值の比較}

新舊兩測定容器を使つて测定した隔離板の電氣抵抗

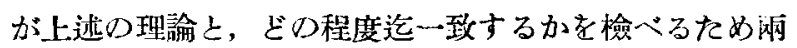
者を使用して, 新測定容器に上る賽测值と鹤测定谷器上 りの計算值との比較をして見た。

實驗に使用した測定裝犆は，第5圖の結線圖に示す如 く完全に遮蔽した交流ブリッヂを使用し，電源として 1,000サイクルの真空管發振器, 零示器として受話器を

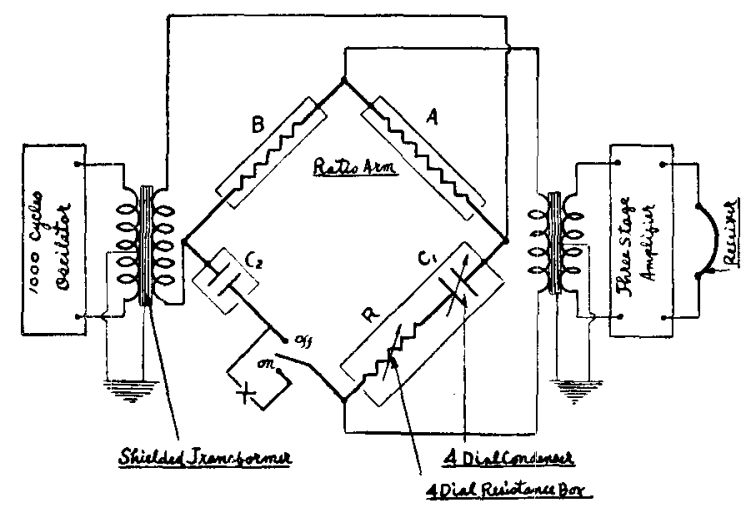

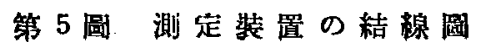

用ひ三段伯輠器によつて感度を增加させた。

第 5 圖中の符號は下記のbのを表はしてるる。

$A ： 0,10,100,1,000 \Omega \bigcirc 4$ 段可變無誘導抵抗

$B: 5,10,100,1,000 \Omega \emptyset \quad "$

$C_{1}: 10 \mu \mu \mathrm{F} \sim 1.111 \mu \mathrm{F}$ 可變脾電器

$C_{\mathrm{a}}: 20 \mu \mathrm{F}$ Ф不變蓄電器

$X ：$ 測定容器及びその抵抗

隔離板の抵抗を測るにはプラッグを on ス入れ，隔離 板を插入しない時の測定容器の热抗 $X$, を测起し次に隔 離板を挿入した洔の測定器の抵抗 $X_{2}$ 老測定し, 兩者の 浽を求めるのである。

かくして新舊兩測起容器を使用して测つた隔離板の電 氣抵抗及び計算値は第 2 表及び第 6 圖の如くである。

表中心數值は比重 $1,200\left(15^{\circ} \mathrm{C}\right.$ に於ける) の稀硫酸中 に於て，10 mmHg の壓力下に約 1 時間放置した後に， 同一比重の稀硫酸中に於て, 常捱下で测つたメボナイト

第 2 表 触测值と計算值との比較

\begin{tabular}{|c|c|c|c|c|}
\hline \multirow{2}{*}{$\begin{array}{c}\text { 液 溫 } \\
\left({ }^{\circ} \mathrm{C}\right)\end{array}$} & \multicolumn{4}{|c|}{ 抵抗 $\left(\Omega / \mathrm{dm}^{2} / \mathrm{mm}\right)$} \\
\hline & $\begin{array}{l}\text { 新容器によ } \\
\text { る測定值 }\end{array}$ & $\begin{array}{c}\text { 舊签器上 } \\
\text { 测定值 } \\
(A)\end{array}$ & $\begin{array}{c}\text { 霊離板之同 } \\
\text { 積の液 } \\
(B)\end{array}$ & $\begin{array}{c}\text { 計 算 偲 } \\
(A+B)\end{array}$ \\
\hline 10 & 0.0106 & 0.0095 & 0.0015 & 0.0110 \\
\hline 20 & 0.0088 & 0.0077 & 0.0013 & 0.0090 \\
\hline 30 & 0.0074 & 0.0066 & 0.0011 & 0.0077 \\
\hline
\end{tabular}

粉木製微孔性隔離板の

電氣抵抗である。

程驗結果は，賽测值 と計算倠とが最大的 4 \%狂つてるるけれども 䉼測定容器の安定性に 引替へて舊测定容器が 甚だしく不安定である ため，乙の程度の誤差 は止むを得ないのであ つて, 新測定容器の實 测侹が計算值と良く一 致してみると見て差支 へない。

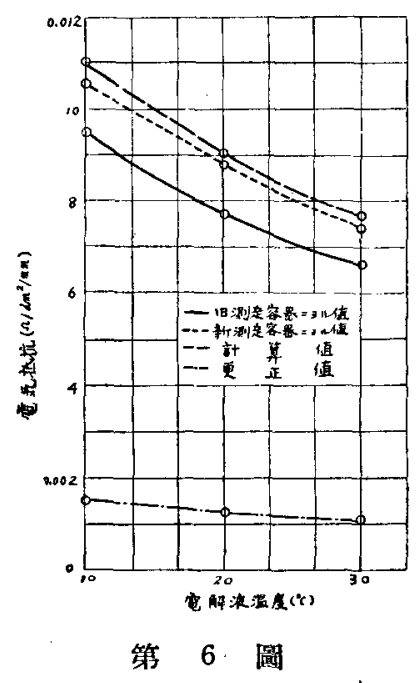

賀測値と計算値との比較

\section{V. 新測定容器による貫驗}

㰾测定容器を使用して木製及び微孔性ゴム隔離板の真 の抵抗を測定した。 
この實驗に於ては，测定せんとする濃度の稀磁酸中に 於て $10 \mathrm{~mm} \mathrm{Hg}$ の壓力下゙に約 1 時間置いた媵, 液中か ら取出して同一濃度の稀硫酸中で測定した值を示した。 䟴度を變へた度每に供試品を取替へて惯驗を行つた。

第 3 表及び第 7 圖は $5^{\circ} \mathrm{C} \sim 35^{\circ} \mathrm{C}$ D溫度に就いて, 3 種 ○木製隔離板郎ち米懀, スプルス及び榀の電埭抵抗を比 重 $1,200\left(15^{\circ} \mathrm{C}\right.$ に於る) の稀硫酸中で测定した俻を示し てねる。

第4表はラテックスを原料とした $\mathrm{A}$ 社製の微孔性ゴ ム隔離板の電氣抵抗で之を圖表化したものが第 8 圆です る。

第 3 表 木製隔成板の電釆抵抗 $\left(\Omega / \mathrm{dm}^{2} / \mathrm{mm}\right)$

\begin{tabular}{|c|c|c|c|c|c|c|c|}
\hline \multirow{2}{*}{ 種 類 } & \multicolumn{7}{|c|}{ 液 温 $\left({ }^{\circ} \mathrm{C}\right)$} \\
\hline & 5 & 10 & 15 & 20 & 25 & 30 & 35 \\
\hline
\end{tabular}

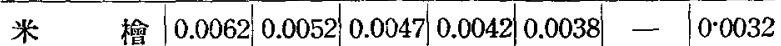

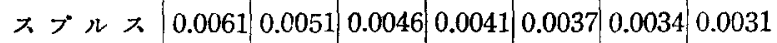

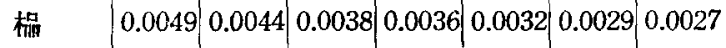

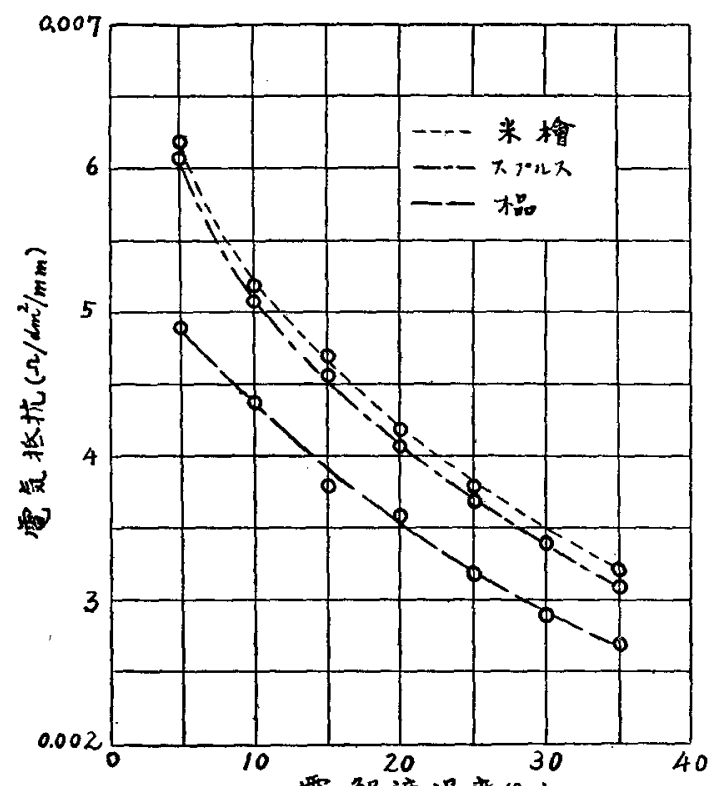

電解液温度 $\left({ }^{\circ} \mathrm{C}\right)$

第 7 圆 木製隔離板の電氣抵抗 $\left(\Omega / \mathrm{dm}^{2} / \mathrm{mm}\right)$

第 4 表 ラテックス製微孔性隔敨板の電氣抵抗 $\left(\Omega / \mathrm{dm}^{2} / \mathrm{mm}\right)$

\begin{tabular}{c|c|c|c|c|c|c|c}
\hline 硫酸の比重 & \multicolumn{7}{|c}{ 液 } \\
\cline { 2 - 7 }$\left(15^{\circ} \mathrm{C}\right)$ & 5 & 10 & 15 & 20 & 25 & 30 & 35 \\
\hline 1,100 & 0.0104 & 0.0096 & 0.0089 & 0.0082 & 0.0078 & 0.0073 & 0.0069 \\
1,200 & 0.0071 & 0.0066 & 0.0061 & 0.0056 & 0.0051 & 0.0048 & 0.0044 \\
1,300 & 0.0078 & 0.0071 & 0.0066 & 0.0059 & 0.0055 & 0.0051 & 0.0046 \\
\hline
\end{tabular}

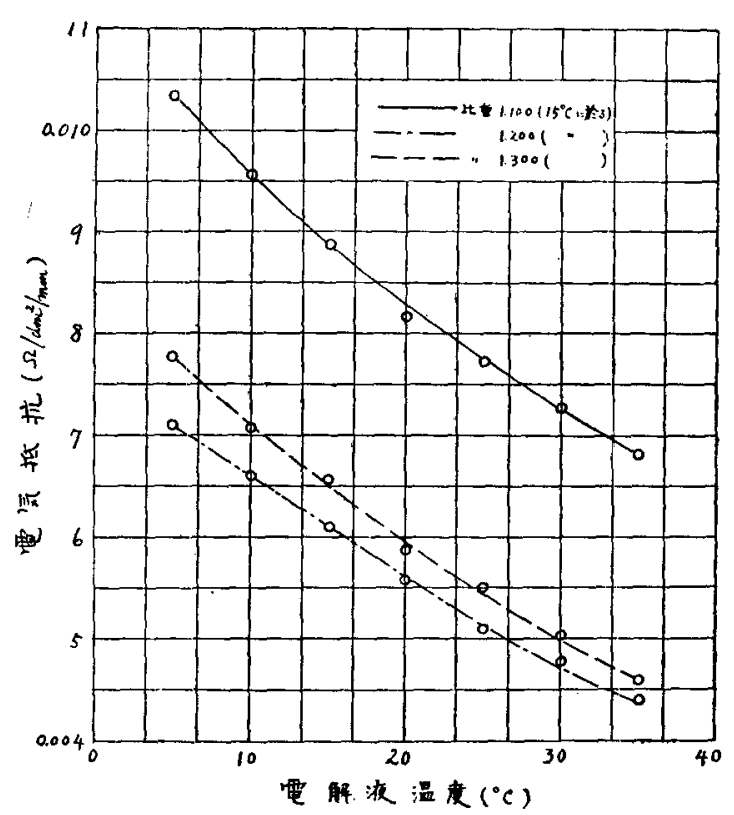

第 8 圖 電氣抵抗一溫度曲線 (ラテックス製)

第 5 表 エボナイト粉末製徽孔性漂離板の電氣担抗 $\left(\Omega / \mathrm{dm}^{2} / \mathrm{mm}\right)$

\begin{tabular}{c|c|c|c|c|c|c|c}
\hline $\begin{array}{c}\text { 硫酸の比重 } \\
\left(15^{\circ} \mathrm{C}\right)\end{array}$ & 5 & 10 & 15 & 20 & 25 & 30 & 35 \\
\hline 1,100 & 0.0094 & 0.0090 & 0.0082 & 0.0075 & 0.0070 & 0.0066 & 0.0061 \\
1,200 & 0.0066 & 0.0061 & 0.0054 & 0.0050 & 0.0046 & 0.0044 & 0.0040 \\
1,300 & 0.0077 & 0.0071 & 0.0063 & 0.0058 & 0.0053 & 0.0048 & 0.0045 \\
\hline
\end{tabular}

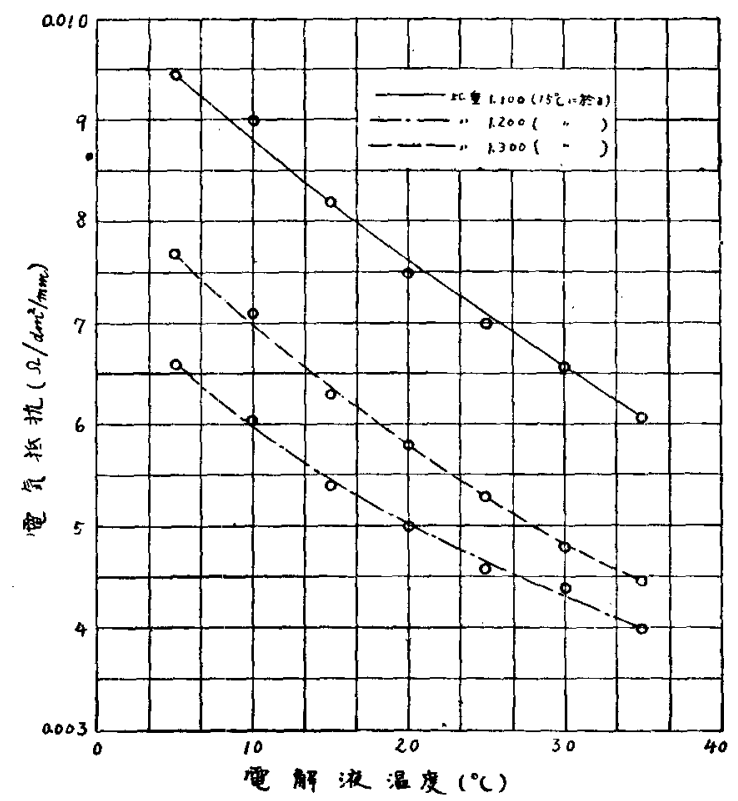

第 9 圆 電埭抵抗一溫度曲線（エボナイト粉末製）

第 5 表はエボナイト粉末を原料上した B 就製D微孔 性ゴム隔離板の電氣抵抗で，第 9 圖は之を圖表化したも 
のである。

エボナィト粉末を原料とした B 型製の徽孔性隔離板 の電氣抵抗は，製品により不同が大きい様でむつたから 製造直啳の新製品を使用した。

VI. 結 言

從來の隔離板電氣抵抗测定容器で测つた值は真の抵抗
より遙かに少い值を示す。

真の抵抗を直接求めるため新測定容器を考案試作し， 該容器で測定した抵抗と從來の測定容器で测つた抵抗か ら計算した值とを比較して見をがよく一致した。

新测定容器は舊測定容器に比し安定且つ良好で使用し 易い利默がある。(昭和 12 年 11 月 11 日受理)

\title{
高周波用絕緣物の研觉第 2 類 \\ チタニウム化合物に關する研㠰 (第 1 報) *
}

\author{
鈴 木 信 一
}

(東京工業大學建築材料研究所)

\begin{abstract}
Abstrakt.
In diesem ersten Bericht beschriebt der Verfasser den allgemeinen Anschaungen für meine Arbeiten und den Verändertung der spezifischen Wiederstand in Abhängigkeit von Temperatur der 24 artigen Titanporzellan, 32 artigen Sinterrutil-Massen versuchte.

Diese Mittelung dient als das Vorwort für meine Dissertationen, welchen aus dreiundzwanzigsten Abteilungen bestehen. (Versuchsanstalt für Baumaterial, Tokio Technische Hochschule)
\end{abstract}

要 旨

第 1 報忙本研究に對する一般的考察及びチタニウム磁器 24 種，ジンタールチル 32 㮔，の比抵抗 と溫度との關係て就て述一゙た。本文は以下 23 篇に亘る拙稿の緒言的意義を有するるのである。

緒雪

本研究の月的は酸化チターウムを主原料として高周波 解縃緣物並答母代用品, 電波レンズ等の製造法を求め併 せて燐酸肥料工業，アルミニウム工業，砂鐵工業等に於 て得らるべきダウム化合物の利用法索確立するにあ る。

近時高周波通信工悬の著しく發達に件ひ短波長及び超 短波の利用が急速に堌加し，絕緗材料儿對して新しい問 題を提出するに到つた，郎ち此の種の電氣機器に使用せ

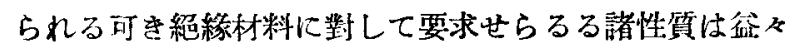
複雜多岐に亘り到底既保の材料に上りては充足し得さる 傾向之なりつ」る。著者は財團法人旭化學工業獎䯇會 菲に志方獎學資金の補助を受け昭和 9 年高周波用絕線物
の研究第 1 類として涩洲及び朝鮮各地て哭盡藏に崖出す る滑在を原料として「滑石磁器の研究」を開始し昭和 12 年 2 月之完成したるを以て，該研究報告は日本工學研 究攝姴昭和 11 年第 2 號及び工業化學雜誌上〔既刊，近 藤清治・铃木信一，第 1 2 報 39（昭 11）552，第 3 $\sim 4$ 報 40，(昭 12）39，第 5 8 報 40，(昭 12）268， 第 9 12 報 40, (昭 12) 991，以下は未刊了發表及 は引續き揭載をなし，實際上の問題としては之が工業上 の實施を見るに到つをものである。著者の研笲に於ては 滑石磁器を分ちて, 高滑石型素地, 滑石原鏡ガス處理燒 成物及低滑石型素地の 3 種となす，即ち前二者は極めて 卓越せる高周波用絕綾物之なし, 又後者は專ら涌熱電氣 磁器として點火栓，水銀整流機除極用絶縁物，電力遮斷

* Forschungen der keramischen Hochfrequenz-Isolierstoffe Gruppe II Untersüchungen über den Titanverbindungen (1) von SHIN-ICHI SUZUKI. 